\title{
Ab Initio Study on the Thermal Decomposition of $\mathrm{CH}_{3} \mathrm{CF}_{2} \mathrm{O}$ Radical
}

\author{
Hari Ji Singh, ${ }^{*}$ Bhupesh Kumar Mishra, and Nand Kishor Gour \\ Department of Chemistry, DDU: Gorakhpur Cmiversin, Gorakhpu-273009, L. P. India \\ E-mail: hari_singhslianhotmail.com \\ Received Jtily 31, 2009, Accepted October 14, 2009
}

\begin{abstract}
The decomposition reaction mechanisn of $\mathrm{CH}_{3} \mathrm{CF}_{2} \mathrm{O}$ radical fomed from hydroflurocarbon, $\mathrm{CH}_{3} \mathrm{CHF}_{2}(\mathrm{HFC}$ $152 \mathrm{a})$ in the atmosphere has been investigated using ab-initio quantum mechanical methods. The geonetries of the reactant, products and transition states involved in the decomposition pathways have been optimized and characterized at DFT-B3LYP and MP2 levels of theories using 6-311+G(d,p) basis set. Calculations have been carried out to observe the effect of basis sets on the optimized geometries of species involved. Single point energy: calculations have been performed at $Q \mathrm{CISD}(\mathrm{T})$ and $\operatorname{CCSD}(\mathrm{T})$ level of theories. Out of the two prominent decomposition channels considered viz., $\mathrm{C}-\mathrm{C}$ bond scission and $\mathrm{F}$-elimination, $\mathrm{C}-\mathrm{C}$ bond scission is found to be the doninant path involving a barrier height of $12.3 \mathrm{kcal} / \mathrm{mol}$ whereas the $\mathrm{F}$-elimination path involves that of a 28.0 $\mathrm{kcal} / \mathrm{mol}$. Using transition-state theory, rate constant for the most dominant decomposition pathway viz., C-C bond scission is calculated at $298 \mathrm{~K}$ and found to be $1.3 \times 10^{-1} \mathrm{~s}^{-1}$. Transition states are searched on the potential energy surfaces involving both decomposition channels and each of the transition states are characterized. The existence of transition states on the corresponding potential energy surface are ascertained by performing Intrinsic Reaction Coordinate (IRC) calculation.
\end{abstract}

Key Words: HFC-152a, Decomposition of HFC, PES. Transition state theory

\section{Introduction}

It is now well established that atomic chlorine transported to the stratosphere by release of a variety of cllorine containing compounds particularly chlorofluorocarbons (CFCs) is responsible for the depletion of ozone layer in this region of atmosphere. CFCs give rise to perhaps the most well known and disastrous environmental problem of destniction of stratospheric ozone layer. ${ }^{1-4}$ CFCs were developed in late $1920 \mathrm{~s}$ in the search for more friendly refrigerants as substitutes for ammonia and sulphur-dioxide. The chemical inertness of CFCs which is one of the desired properties is also the properties that cause them to be environmentally unfriendly. Once released in the atmosphere CFCs remains there for a longer period of time because they do not react with $\mathrm{OH}$ or $\mathrm{NO}_{2}$ radicals formed in the atmosphere. However. it absorbs short wavelengths UV radiations generating $\mathrm{Cl}$ free radicals responsible for the catalytic destniction of ozone layer. The threat of CFCs to the ozone layer was considered so serious that an intemational treaty (1987 Montréal Protocol) was developed to prohibit production and use of CFCs and most other chemicals causing ozone depletion.

After the global alarm about the deleterious effect of CFCs in the atmosphere. serious efforts for finding out substitutes of these stable CFCs are made during the past decades. Various hydrofluorocarbons (HFCs) and hydrochloroflurocarbons (HCFCs) having plysicochemical properties similar to CFCs have been syththesized and put into global use as an alternative to $\mathrm{CFCs}{ }^{5-5}$ The essential advantages shared by the proposed substitutes with respect to their ozone depletion potential are their incomplete halogenation. HFCs have been proposed as environmentally friendly replacement for CFCs in many applications primarily because the former have little potential for contributing to stratospheric ozone destruction as HFCs con- tain no chlorine to catalyze stratospheric ozone. On the other hand they do contain alkyl hydrogen which is readily abstracted by atmospheric hydroxyl radicals. initiating its tropospheric deconposition. 8

One of the most widely used HFC as an alternative to trichlorofluoromethane (CFC-1I) and dichlorofluoromethane (CFC12 ) is 1.1-difluoroethane (HFC-152a). HFC-152a is a colorless flammable gas with a slight ethereal odor used as a non-ozone depleting aerosol propellant and as an alternative in foam applications. Other potential uses include refrigeration blends and catalyst regeneration. Its global warming potential (GWP) is deternined to be 140 relative to $\mathrm{CO}_{2}{ }^{9}$ due to its relatively short tropospheric lifetime of about one and a-half year. HFC -152 a is degraded into the atmosphere by reaction with photochemically produced hydroxyl radicals. This is the dominant path for removing these conpounds from troposplere. A general mechanism of tropospheric degradation mechanism of HFC-152a may be shown as follows

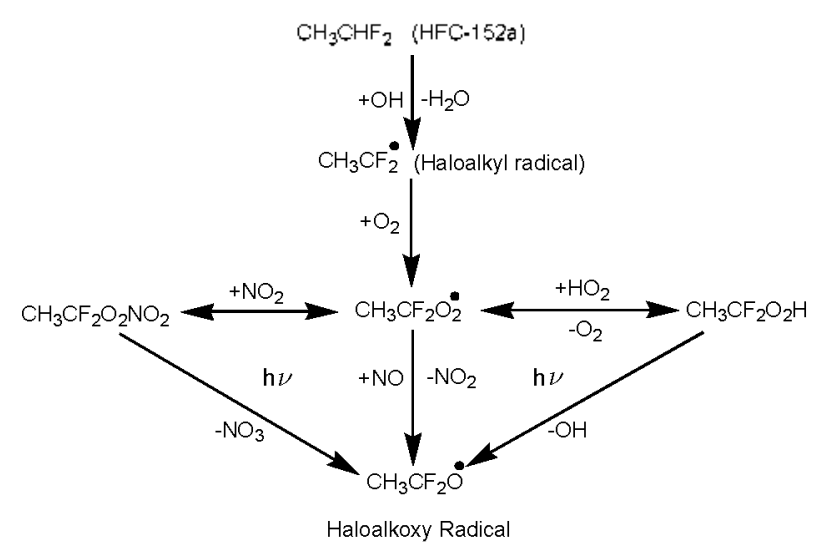

Scheme 1. Tropospheric degradation mechanism of HFC-152a 
The above scheme is based on the fact that the initial attack of $\mathrm{OH}$ radical on $\mathrm{HFC}-152 \mathrm{a}$ leads to the formation of haloalkyl radical $\left(\mathrm{CH}_{3} \mathrm{CF}_{2}{ }_{2}\right)$ which in turn react with atmospheric $\mathrm{O}_{2}$ to give peroxy radicals $\left(\mathrm{CH}_{3} \mathrm{CF}_{2} \mathrm{O}_{2}\right)^{11}$. The latter react further with NO leading to the formation of haloalkoxy radical $\left(\mathrm{CH}_{3} \mathrm{CF}_{2} \mathrm{O}^{\circ}\right)$ via a short-lived intermediate. the perosy nitrate $\left(\mathrm{CH}_{3} \mathrm{CF}_{2} \mathrm{O}_{2} \mathrm{NO}_{2}\right)$. On the other hand haloalkoxy radical may also be generated through another intermediate. the hydroperoxide $\left(\mathrm{CH}_{3} \mathrm{CF}_{2} \mathrm{O}_{2} \mathrm{H}\right)$ formed by the reaction of $\mathrm{CH}_{3} \mathrm{CF}_{2} \mathrm{O}_{2}$ and $\mathrm{HO}_{2}$ radicals. The haloalkoxy radicals thus formed play an important role in the degradation mechanism of organic compounds in the troposphere. ${ }^{13-13}$ There are two potentially accessible decomposition pathways that involve $\mathrm{C}-\mathrm{C}$ bond scission and $\mathrm{F}$-elimination as shown below:

$$
\begin{aligned}
\mathrm{CH}_{3} \mathrm{CF}_{2} \mathrm{O} & \longrightarrow \mathrm{CH}_{3}+\mathrm{CF}_{2} \mathrm{O} \\
& \longrightarrow \mathrm{CH}_{3} \mathrm{C}(\mathrm{O}) \mathrm{F}+\mathrm{F}
\end{aligned}
$$

Studying the fate of haloalkoxy radicals thus formed is important from the viewpoint of understanding its role in atmospheric chemistry. A few experimental study of the decomposition of $\mathrm{CH}_{3} \mathrm{CF}_{2} \mathrm{O}^{\circ}$ radical was carried out by Wallington et $a l^{14}$ No theoretical evidence is reported to date. To explain the experimental results and to predict the new characteristics about the loss of $\mathrm{CH}_{3} \mathrm{CF}_{2} \mathrm{O}^{\circ}$ radical, a theoretical investigation is most desirable. In this paper we present a theoretical study on the thermal decomposition of $\mathrm{CH}_{3} \mathrm{CF}_{2} \mathrm{O}^{\circ}$ radical using the high-level $a b$-initio molecular orbital method.

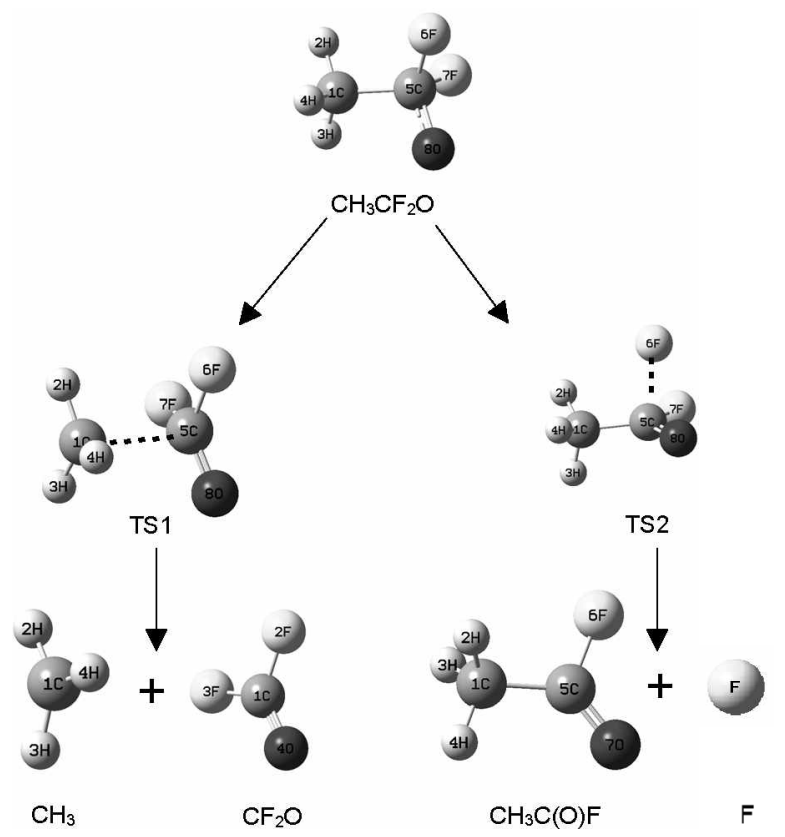

Figure 1. Optinized geometries of reactant, products and transition states involved in the decomposition of $\mathrm{CH}_{2} \mathrm{CF}_{2} \mathrm{O}$ using $\mathrm{B} 3 \mathrm{LYP} / 6-$ $311+\mathrm{G}(\mathrm{d}, \mathrm{p})$ method.

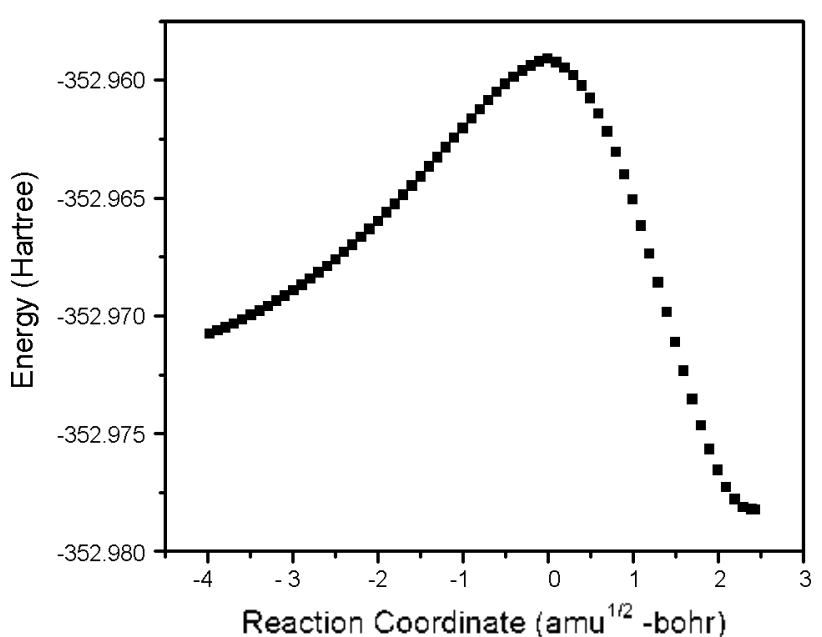

Figure 2. IRC plot for the transition state TSl for C-C bond scission in the $\mathrm{CH}_{3} \mathrm{CF}_{2} \mathrm{O}$ decomposition.

\section{Computational Method}

Ab-initio quautun mechanical calculations ${ }^{15}$ were performed with the GAUSSIAN0 $3^{16}$ package. Geometry optimization of the reactant, products and transition states were performed using density functional study (DFT) employing Becke's three-parameter hy brid functional (B3LYP) ${ }^{1:-18}$ with the $6-311+\mathrm{G}(\mathrm{d}, \mathrm{p})$ basis set. The vibrational frequencies were obtained at the same level to detennine the nature of different stationary points on the potential energy surface. All the stationary points have been identified to be the minima with no imaginary frequency (NIMAG $=0$ ) and the transition states with one inaginary frequency (NIMAG $=1$ ). To ascertain that the identified transition states connect reactant and products smoothly. Intrinsic Reaction Coordinate (IRC) calculations ${ }^{19-201}$ were performed at the B3LYP/6-311++G(d.p) level. In order to refine the energy values. single-point energy calculations were performed at the $\mathrm{QCISD}(\mathrm{T})^{-1}$ and $\mathrm{CCSD}(\mathrm{T})^{-2-}$ level of theories using fairly large basis sets such as $6-311+\mathrm{G}(3 \mathrm{df} .3 \mathrm{pd})$. In order to correct the total energy. zero-point energy calculations were made at B3LYP/ $6-311++G(d, p)$ level. ${ }^{17} .18$

\section{Results and Discussion}

The fate of haloalkosy radical $\left(\mathrm{CH}_{2} \mathrm{CF}_{2} \mathrm{O}\right)$ considered during the course of present investigation is predoninantly its thernal decomposition in the atmosphere. Two dominant decomposition pathways considered (reactions 1 and 2) involve transition states TS1 and TS2 respectively. Optimized geometries of reactant, products and transition states were done at $\mathrm{B} 3 \mathrm{LYP} /$ $6-311++G(d . p)$ and $M P 2 / 6-311++G(d . p)$ level of theories. Results obtained at B3LYP level are shown in Figure 1. Geometrical parameters obtained at both levels are recorded in Table 1. The results show that stnuctural parameters are almost the same with both methods except in the case of TSl structure. In the optimized structure of TSI the elongation of the $\mathrm{C}-\mathrm{C}$ bond using B3LYP method is found to be $2.046 \mathrm{~A}$ whereas at MP2 the value is only $1.870 \mathrm{~A}$. Results obtained during frequency calculations for reactant products and transition 
Table 1. Structural parameters of reactant, products and transition states involved in $\mathrm{CH}_{3} \mathrm{CF}_{2} \mathrm{O}$ decomposition at $\mathrm{B} 3 \mathrm{LYP} / 6-31 \mathrm{l}++\mathrm{G}(\mathrm{d}, \mathrm{p})$ (first line) and $\mathrm{MP} 2 / 6-311++\mathrm{G}(\mathrm{d}, \mathrm{p})$ ( (second line)

\begin{tabular}{|c|c|c|c|c|c|c|}
\hline & $\mathrm{CH}_{3} \mathrm{CF}_{2} \mathrm{O}$ & TS1 & TS2 & $\mathrm{CH}_{3}$ & $\mathrm{CF}_{2} \mathrm{O}$ & $\mathrm{CH}_{3} \mathrm{C}(\mathrm{O}) \mathrm{F}$ \\
\hline \multicolumn{7}{|l|}{ Bond length $(\hat{1})$} \\
\hline $\mathrm{R}(\mathrm{Cl}-\mathrm{C} 5)$ & $\begin{array}{l}1.536 \\
1.513\end{array}$ & $\begin{array}{l}2.046 \\
1.870\end{array}$ & $\begin{array}{l}1.491 \\
1.493\end{array}$ & - & - & $\begin{array}{l}1.495 \\
1.495\end{array}$ \\
\hline $\mathrm{R}(\mathrm{C} 5-08)$ & $\begin{array}{l}1.326 \\
1.347\end{array}$ & $\begin{array}{l}1.200 \\
1.200\end{array}$ & $\begin{array}{l}1.225 \\
1.220\end{array}$ & - & - & - \\
\hline $\mathrm{R}(\mathrm{C} 5-07)$ & $\begin{array}{l}- \\
-\end{array}$ & - & - & - & - & $\begin{array}{l}1.182 \\
1.188\end{array}$ \\
\hline $\mathrm{R}(\mathrm{C} 1-04)$ & - & - & - & - & $\begin{array}{l}1.171 \\
1.176\end{array}$ & - \\
\hline $\mathrm{R}(\mathrm{Cl}-\mathrm{H} 2)$ & $\begin{array}{l}1.093 \\
1.090\end{array}$ & $\begin{array}{l}1.084 \\
1.086\end{array}$ & $\begin{array}{l}1.094 \\
1.093\end{array}$ & $\begin{array}{l}1.081 \\
1.079\end{array}$ & - & $\begin{array}{l}1.092 \\
1.092\end{array}$ \\
\hline $\mathrm{R}(\mathrm{Cl}-\mathrm{H} 3)$ & $\begin{array}{l}1.088 \\
1.089\end{array}$ & $\begin{array}{r}1.082 \\
1.08\end{array}$ & $\begin{array}{l}1.089 \\
1.089\end{array}$ & $\begin{array}{l}1.081 \\
1.079\end{array}$ & - & $\begin{array}{l}1.092 \\
1.092\end{array}$ \\
\hline $\mathrm{R}(\mathrm{Cl}-\mathrm{H} 4)$ & $\begin{array}{l}1.088 \\
1.089\end{array}$ & $\begin{array}{l}1.082 \\
1.083\end{array}$ & $\begin{array}{r}1.087 \\
1087\end{array}$ & 1.081 & - & $\begin{array}{l}1.087 \\
1.087\end{array}$ \\
\hline$R(C 5-F 6)$ & $\begin{array}{l}1.375 \\
1.362\end{array}$ & $\begin{array}{l}1.355 \\
1.353\end{array}$ & $\begin{array}{l}1.952 \\
1.796\end{array}$ & - & - & 1.373 \\
\hline $\mathrm{R}(\mathrm{C} 5 \mathrm{~F} 7)$ & $\begin{array}{l}1.375 \\
1.362\end{array}$ & $\begin{array}{l}1.355 \\
1.353\end{array}$ & $\begin{array}{l}1.342 \\
1.335\end{array}$ & - & - & - \\
\hline $\mathrm{R}(\mathrm{C} 1-\mathrm{F} 2)$ & - & - & - & - & 1.322 & - \\
\hline $\mathrm{R}(\mathrm{Cl}-\mathrm{F} 3)$ & - & - & - & - & $\begin{array}{l}1.30 \\
1.322 \\
1.318\end{array}$ & - \\
\hline \multicolumn{7}{|l|}{ Bond Angle (deg) } \\
\hline $\mathrm{A}(\mathrm{H} 2-\mathrm{C} 1-\mathrm{H} 3)$ & $\begin{array}{l}110.057 \\
109.777\end{array}$ & $\begin{array}{l}117.282 \\
116.316\end{array}$ & $\begin{array}{l}108.436 \\
109.072\end{array}$ & $\begin{array}{l}119.984 \\
119.999\end{array}$ & - & $\begin{array}{l}107.422 \\
107.713\end{array}$ \\
\hline $\mathrm{A}(\mathrm{H} 2-\mathrm{Cl}-\mathrm{H} 4)$ & $\begin{array}{l}110.057 \\
110.500\end{array}$ & $\begin{array}{l}117.282 \\
116.316\end{array}$ & $\begin{array}{l}110.039 \\
111.375\end{array}$ & $\begin{array}{r}120.001 \\
120.00\end{array}$ & - & $\begin{array}{l}110.260 \\
110.260\end{array}$ \\
\hline $\mathrm{A}(\mathrm{H} 3-\mathrm{C} 1-\mathrm{H} 4)$ & $\begin{array}{l}110.804 \\
110.500\end{array}$ & $\begin{array}{l}116.965 \\
116.609\end{array}$ & $\begin{array}{l}109.624 \\
109.969\end{array}$ & $\begin{array}{l}120.016 \\
120.002\end{array}$ & - & $\begin{array}{l}110.256 \\
110.438\end{array}$ \\
\hline $\mathrm{A}(\mathrm{Cl}-\mathrm{C} 5-\mathrm{F} 6)$ & $\begin{array}{l}110.318 \\
110.964\end{array}$ & $\begin{array}{r}97.803 \\
100.054\end{array}$ & $\begin{array}{l}102.516 \\
111.686\end{array}$ & - & - & $\begin{array}{l}110.263 \\
109.950\end{array}$ \\
\hline $\mathrm{A}(\mathrm{F} 6-\mathrm{C} 5-\mathrm{F} 7)$ & $\begin{array}{l}105.042 \\
105.481\end{array}$ & $\begin{array}{l}106.382 \\
105.714\end{array}$ & $\begin{array}{r}99.729 \\
100.753\end{array}$ & - & - & - \\
\hline$A(F 6-C 5-08)$ & $\begin{array}{l}111.982 \\
110.598\end{array}$ & $\begin{array}{l}123.139 \\
122.819\end{array}$ & $\begin{array}{l}81.924 \\
82.288\end{array}$ & - & - & - \\
\hline $\mathrm{A}(\mathrm{F} 6-\mathrm{C} 5-\mathrm{O} 7)$ & - & - & - & - & - & $\begin{array}{l}119.874 \\
120.304\end{array}$ \\
\hline$A(F 2-C l-F 3)$ & - & - & - & - & 108.289 & - \\
\hline $\mathrm{A}(\mathrm{F} 2-\mathrm{C} 1-\mathrm{O} 4)$ & - & - & - & - & $\begin{array}{l}107.484 \\
125.856\end{array}$ & - \\
\hline & - & - & - & - & 126.257 & - \\
\hline
\end{tabular}

states using both methods are recorded in Table 2 . The result shows that value obtained using MP2 method are slightly ligher than that of B3LYP. These results also show that the reactant and products have stable minima on their potential energy surface characterized by the occurrence of real vibrational frequencies. Transition states TSI and TS2 are characterized by the occurrence of only one imaginary frequency as obtained during the frequency calculation. Results recorded in Table 2 show the values at 453 and $285 \mathrm{~cm}^{-1}$ for TSl and TS2 respectively at B3LYP level whereas at MP2 the respective values are 768 and $1163 \mathrm{~cm}^{-1}$. These frequencies are analyzed using the GaussView program. ${ }^{73}$ Visualization of vibrations corresponding to the calculated imaginary frequencies show the well defined transition state geometries connecting reactant and products during transition. In order to ascertain the existence of transition state on the potential energy surface Instrinsic Reaction Coordinate (IRC) calculations are also performed for each of the transition states determined. The IRC plots for TS 1 and TS2 are shown in Figs 2 and 3 respectively. The IRC calculations show that each transition state smoothly connects the reactant and products on the potential energy surface. Visualization of the optimized stnucture of TSl reveals the elongation of $\mathrm{C}-\mathrm{C}$ bond length $(1.536 \AA$ to $2.046 \mathrm{~A}$ at B $3 \mathrm{LYP}$ and $1.513 \AA$ to $1.870 \mathrm{~A}$ ) with a sinultaneous slurinkage of the $\mathrm{C}-\mathrm{O}$ distance from $1.326 \AA$ to $1.20 \AA$ and forming a carbonoxygen double bond. Sintilarly the structure of TS2 reveals the elongation of $\mathrm{C}-\mathrm{F}$ bond length from $1.375 \AA$ to $1.952 \AA$ at $\mathrm{B} 3 \mathrm{LYP}$ and $1.362 \AA$ to $1.796 \AA$ at MP2 accompanied by a 
Table 2. Unscaled vibrational frequencies of reactant, products and transition states in $\mathrm{CH}_{3} \mathrm{CF}_{2} \mathrm{O}$ decomposition at B3LYP/6-311++G(d,p) (first line) and MP2/6 $311+\mathrm{G}(\mathrm{d}, \mathrm{p}$ ) (second line) levels of theory

\begin{tabular}{|c|c|}
\hline Species & Vibrational frequencies $\left(\mathrm{cm}^{-1}\right)$ \\
\hline $\mathrm{CH}_{3} \mathrm{CF}_{2} \mathrm{O}$ & $\begin{array}{l}173,327,349,524,530,537,790,896,922,1059,1149,1233,1385,1445,1485,3052,3141,3170 \\
214,339,363,526,551,563,840,941,972,1202,1209,1287,1421,1489,1506,3116,3220,3233\end{array}$ \\
\hline TSl & $\begin{array}{l}\mathbf{4 5 3 i}, 128,230,250,533,563,567,649,661,859,1062,1081,1414,1427,1682,3090,3255,3264 \\
768 \mathrm{i}, 184,284,316,553,590,614,791,800,892,1111,1165,1443,1463,1694,3139,3309,3332\end{array}$ \\
\hline TS2 & $\begin{array}{l}\mathbf{2 8 5 i}, 159,171,271,422,487,587,840,1007,1027,1222,1402,1458,1471,1613,3050,3125,31 \\
1163 i, 201,241,316,441,527,606,872,997,1047,1256,1419,1483,1494,1624,3109,3206,32\end{array}$ \\
\hline $\mathrm{CH}_{2} \mathrm{C}(\mathrm{O}) \mathrm{F}$ & $\begin{array}{l}124,414,570,596,816,1000,1068,1180,1403,1469,1474,1912,3051,3112,3159 \\
133,420,573,601,836,1020,1076,1206,1421,1489,1495,1902,3110,3197,3235\end{array}$ \\
\hline $\mathrm{CH}_{3}$ & $\begin{array}{l}537,1401,1403,3102,3281,3283 \\
462,1445,1446,3176,3370,3371\end{array}$ \\
\hline $\mathrm{CF}_{2} \mathrm{O}$ & $\begin{array}{l}575,614,772,955,1201,1974 \\
586,620,783,965,1232,1974\end{array}$ \\
\hline
\end{tabular}

Table 3. Zero-point energy contected total energies for species involved in $\mathrm{C}-\mathrm{C}$ bond scission from $\mathrm{CH}_{3} \mathrm{CF}_{2} \mathrm{O}$ decomposition. [Geometries were optimized at B3LYP/6-311 $+\mathrm{G}(\mathrm{d}, \mathrm{p})$ level] (unit: hatree)

\begin{tabular}{|c|c|c|c|c|}
\hline Method & $\mathrm{CH}_{3} \mathrm{CF}_{2} \mathrm{O}$ & TSl & $\mathrm{CH}_{3}$ & $\mathrm{CF}_{2} \mathrm{O}$ \\
\hline $\operatorname{CCSD}(\mathrm{T}) / 6-311+\mathrm{G}(\mathrm{d})$ & -352.133911 & -352.111880 & -39.677750 & -312.448031 \\
\hline $\operatorname{cosD}(\mathrm{T}) / 6-\hat{3} 11+\mathrm{G}(\mathrm{d}, \mathrm{p})$ & -352.156806 & -352.135128 & -39.705041 & -312.450499 \\
\hline $\operatorname{cosD}(\mathrm{T}) / 6-311++\mathrm{G}(\mathrm{d}, \mathrm{p})$ & -352.157072 & -352.135432 & -39.705194 & -312.450499 \\
\hline $\operatorname{cosD}(\mathrm{T}) / 6-311 \mathrm{G}(\mathrm{d}, \mathrm{p})$ & -352.139472 & -352.118554 & -39.703765 & -312.436842 \\
\hline $\operatorname{CcsD}(\mathrm{T}) / 6-311++\mathrm{G}(3 \mathrm{df}, 3 \mathrm{pd})$ & -352.363068 & -352.343380 & -39.729701 & -312.627872 \\
\hline $\operatorname{QCISD}(\mathrm{T}) / 6-311+\mathrm{G}(\mathrm{d}, \mathrm{p})$ & -352.158037 & -352.137219 & -39.705094 & -312.449439 \\
\hline $\operatorname{CCISD}(\mathrm{T}) / 6-311 \mathrm{G}(\mathrm{d}, \mathrm{p})$ & -352.140512 & -352.120484 & -39.700871 & -312.435955 \\
\hline ZPE B3LYP/6-311++G(d,p) & 0.050517 & 0.047205 & 0.029651 & 0.013875 \\
\hline
\end{tabular}

shrinkage of the $\mathrm{C}-\mathrm{O}$ bond as recorded in Table $\mathrm{L}$.

Single point energy calculations of various species involved in the decomposition pathway's are performed using CCSD (T) and QCISD(T) level of theories at B3LYP/6-31++G(d.p) optimized geometries. In order to refine the values. these calcullations are also performed using larger basis sets incorporating polarized and diffused basis sets. Calculated total energies are corrected for zero-point energy. the latter being calculated at B3LYP using $6-311++G(d, p)$ basis using a scale factor of $0.96{ }^{15}$ Zero-point corrected total energies using standard and extended basis sets for various species and transition states involved in decomposition reactions (1) and (2) are recorded in Tables 3 and 4 . The computed data shows that most favorable decomposition channel for $\mathrm{CH}_{3} \mathrm{CF}_{2} \mathrm{O}$ is the $\mathrm{C}-\mathrm{C}$ bond scission involving an energy barrier of $12.3 \mathrm{kcal} \mathrm{mol}^{-1}$. The associated energy barriers corresponding to decomposition pathway's of $\mathrm{CH}_{3} \mathrm{CF}_{2} \mathrm{O}$ calculated from the results obtained at various level of theories are shown in Table 5 . These results show that energy barrier for $\mathrm{C}-\mathrm{C}$ bond scission is in the range of $12-13 \mathrm{kcal} / \mathrm{mol}$ whereas for $\mathrm{F}$-elimination it is in the range of $26 \cdot 28 \mathrm{kcal} / \mathrm{mol}$ depending upon the levels of theories involved during the calculation. Literature survey reveals that there is no experimental data available for the comparison of

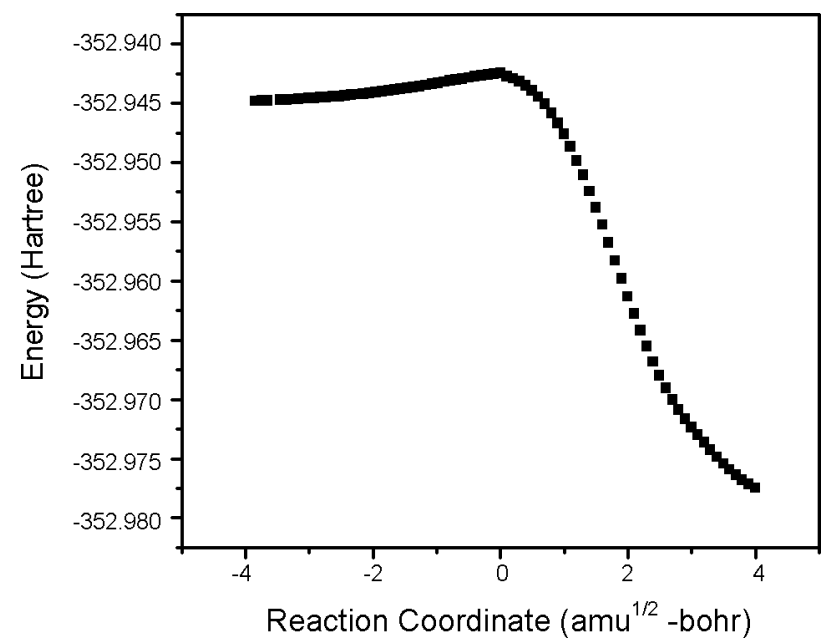

Figure 3. IRC plot for the transition state $\mathrm{TS} 2$ for $\mathrm{F}$-elimination in the $\mathrm{CH}_{3} \mathrm{CF}_{2} \mathrm{O}$ decomposition.

these energy barriers for the corresponding decomposition pathways of $\mathrm{CH}_{3} \mathrm{CF}_{2} \mathrm{O}$ radical. However. to ascertain the reliability of the calculated values during the course of the present 
Table 4. Zero-point energy corrected total energies for species involved in F-elimination from $\mathrm{CH}_{3} \mathrm{CF}_{2} \mathrm{O}$ decomposition. [Geometries optimized at B 3 LYP/6

\begin{tabular}{|c|c|c|c|c|}
\hline Method & $\mathrm{CH}_{2} \mathrm{CF}_{2} \mathrm{O}$ & TS2 & $\mathrm{CH}_{3} \mathrm{C}(\mathrm{O}) \mathrm{F}$ & $\mathrm{F}$ \\
\hline $\operatorname{CCSD}(\mathrm{T}) / 6-311+\mathrm{G}(\mathrm{d})$ & -352.133911 & -352.091590 & -252.528892 & -99.571581 \\
\hline $\operatorname{CCSD}(T) / 6-311+G(d, p)$ & -352.156806 & -352.114237 & -252.551730 & -99.571581 \\
\hline $\operatorname{CCSD}(T) / 6-311++G(\mathrm{~d}, \mathrm{p})$ & -352.157072 & -352.114488 & -252.551928 & -99.571581 \\
\hline $\operatorname{ccs} D(\mathrm{~T}) / 6-311 \mathrm{G}(\mathrm{d}, \mathrm{p})$ & -352.139472 & -352.095662 & -252.540308 & -99.565746 \\
\hline $\operatorname{cosD}(\mathrm{T}) / 6-31 \mathrm{l}++\mathrm{G}(3 \mathrm{df}, 3 \mathrm{pd})$ & -352.363068 & -352.318447 & -252.704410 & -99.61769 \\
\hline QCISD $(T, / 6-311+G(d, p)$ & -352.158037 & -352.116335 & -252.552955 & -99.571685 \\
\hline QCISD $(T / 6-311 \mathrm{G}(\mathrm{d}, \mathrm{p})$ & -352.140512 & -332.097519 & -252.541440 & -99.565804 \\
\hline ZPE B3.LYP/6-3̂l1++G(d,p) & 0.050517 & 0.048959 & 0.048649 & 0.000 \\
\hline
\end{tabular}

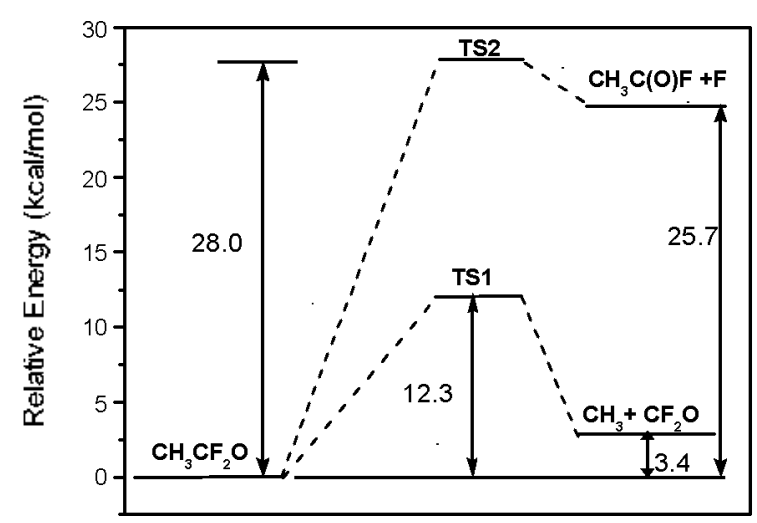

Figure 4. Energy diagram for $\mathrm{CH}_{2} \mathrm{CF}_{2} \mathrm{O}$ decomposition channels calculated at CCSD(T) $6-311++\mathrm{G}(3 \mathrm{dt}, 3 \mathrm{pd})$ level on the geometries optinized at B3LYP/6-311++G(d,p) level.

study using a particular method a comparison is made with the energy values calculated by Hou $e$ $a l^{24}$ for a structurally similar compound $\mathrm{CH}_{3} \mathrm{CHFO}$ made at a considerably higher level using $\mathrm{G} 2 / \mathrm{MP} 2 / 6-31 \mathrm{G}$ (d) method. In $\mathrm{CH}_{3} \mathrm{CHFO}$ the energy barrier for $\mathrm{C}-\mathrm{C}$ bond scission has been shown to be $11.6 \mathrm{kcal} /$ $\mathrm{mol}^{2+}$ whereas the calculated value during the present study for $\mathrm{C}-\mathrm{C}$ bond scission in $\mathrm{CH}_{3} \mathrm{CF}_{2} \mathrm{O}$ is $12.3 \mathrm{kcal} / \mathrm{mol}$ at $\mathrm{CCSD}$ (T) level with the largest basis set used. These values show a good agreement. This gives us a confidence to use single point energy calculation data obtained using $\operatorname{CCSD}(\mathrm{T}) / 6-3 \mathrm{ll}++\mathrm{G}$ (3df.3pd) method on the geometries optimized at B3LYP/6$311++G(d . p)$ level to calculate energy barriers for two decomposition channels of $\mathrm{CH}_{3} \mathrm{CF}_{2} \mathrm{O}$ radical considered in the present study. An energy diagram is constructed (Figure 4) with the zero-point corrected energies data recorded in Tables 4 and 5 relative to the ground state energy of $\mathrm{CH}_{3} \mathrm{CF}_{2} \mathrm{O}$ arbitrarily taken as zero. The barrier height of $12.3 \mathrm{kcal} \mathrm{mol}^{-1}$ for $\mathrm{C}-\mathrm{C}$ bond scission is considerably lower than that corresponding to $\mathrm{F}$-elimination process. This makes the $\mathrm{C}-\mathrm{C}$ bond scission pathway as the dominant process for the dissociation of this haloalkoxy radical in the atmosphere. Results recorded in Table 5 also show that energy barriers calculated using polarized function is slightly higher than that without polarized functions. Spin contamination is not important for the $\mathrm{CH}_{3} \mathrm{CF}_{2} \mathrm{O}$ radical because $\left\langle\hat{S^{2}}\right\rangle$ is in the range of 0.758 at HF/6-31G(d) to 0.76 at $\mathrm{MP} 2 / 6-311+\mathrm{G}(\mathrm{d}, \mathrm{p})$ before anniluilation that are only slightly larger than the expected value of $\left\langle\mathrm{S}^{2}\right\rangle=0.75$ for doublets.
Table 5. Calculated energy barriers in kcal mol ${ }^{-3}$

\begin{tabular}{lcc}
\hline \multicolumn{1}{c}{ Method } & C-C bond scission & F-elimination \\
\hline $\operatorname{CCSD}(\mathrm{T}) / 6-311 \mathrm{G}(\mathrm{d}, \mathrm{p})$ & 13.1 & 26.5 \\
$\operatorname{CCSD}(\mathrm{T}) / 6-311+\mathrm{G}\left(\mathrm{d}_{\mathrm{p}} \mathrm{p}\right)$ & 13.6 & 26.7 \\
QCISD $(\mathrm{T}) / 6-311 \mathrm{G}(\mathrm{d}, \mathrm{p})$ & 12.6 & 26.9 \\
QCISD(T)/6-311+G(d,p) & 13.0 & 26.1 \\
$\operatorname{CCSD}(\mathrm{T}) / 6-31 \mathrm{l}+\mathrm{G}(3 \mathrm{df}, 3 \mathrm{pd})$ & 12.3 & 28.0 \\
\hline
\end{tabular}

\section{Rate Constants}

The rate constants of decomposition reactions ( 1 ) and (2) of $\mathrm{CH}_{3} \mathrm{CF}_{2} \mathrm{O}$ radical is calculated using Canonical Transition State Theory $(\mathrm{CTST})^{2.5}$ that involves a seni-classical one-dimensional multiplicative tunneling correction factor. The rate constants are computated using the following expression:

$$
k=\Gamma(T) \frac{k_{S} T}{h} \frac{Q^{-} T S}{Q_{R}} \exp \frac{ - \pm E}{R T}
$$

where $\Gamma(\mathrm{T})$ is the tunneling correction factor at temperature T. $Q^{-}{ }_{T S}$ and $Q_{R}$ are the total partition functions for the transition state and reactant respectively. $J E . k_{B}$ and $h$ are the barrier height. Boltzmann's and Planck's constants respectively. We adopted the simple and computationally inexpensive Wigner's method $^{26}$ for the estimation of the tunneling correction factor using the expression

$$
\Gamma(T)=1+\frac{1}{24}\left|\frac{h v^{m}}{k_{B} T}\right|^{2}
$$

where $v^{*}$ is the imaginary frequency at the saddle point. The tunneling correction factor $\Gamma(T)$ is found to be almost unity. The partition functions for the respective transition state and reactant at $298 \mathrm{~K}$ are obtained from the harmonic vibrational frequencies calculated at the B3LYP/6-311++G(d,p) level. The rate constant for $\mathrm{C}-\mathrm{C}$ bond scission in $\mathrm{CH}_{2} \mathrm{CF}_{2} \mathrm{O}$ decomposition is calculated to be $1.3 \times 10^{4} \mathrm{~s}^{-1}$ at $298 \mathrm{~K}$ and 1 atm pressure. Literature survey reveals that there is no experimental available in the literature to make a comparison with the calculated values obtained during the present investigation. However based on an analogy with the decomposition of other oxy-radicals for C-C bond scission our calculated value comes 
out to be of the same order of magnitude. ${ }^{? ?}$ Our modeling calculation also results the A-factor for $\mathrm{C}-\mathrm{C}$ bond scission to be $1.3 \times 10^{13} \mathrm{~s}^{-1}$ which is also in good agreement with the value of $1.1 \times 10^{13} \mathrm{~s}^{.1}$ for $\mathrm{CH}_{3} \mathrm{CH}_{2} \mathrm{O}$ obtained by Caralp et al. ${ }^{3 \times}$ Similarly, the rate constant for F-elimination via reaction 2 involving TS2 as the transition state is calculated to be $4.4 \times 10^{-8} \mathrm{~s}^{-1}$ at $298 \mathrm{~K}$ and 1 atm pressure with the associated A factor of $1.4 \times$ $10^{13} \mathrm{~s}^{-1}$.

\section{Conclusion}

The most important stationary points on the potential energy surface for the thermal decomposition of $\mathrm{CH}_{3} \mathrm{CF}_{3} \mathrm{O}$ radical are investigated using $a b$-initio quantum mechanical methods QCISD $(T)$ and $\operatorname{CCSD}(T)$ of the geometries optimized at $\mathrm{B} 3 \mathrm{LYP} / 6-311++\mathrm{G}(\mathrm{d}, \mathrm{p})$ for all the species involved during the decomposition channels of $\mathrm{CH}_{3} \mathrm{CF}_{2} \mathrm{O}$ radical. Energetic calculation reveals that the most dominant decomposition pathway's for $\mathrm{CH}_{3} \mathrm{CF}_{2} \mathrm{O}$ is the $\mathrm{C}-\mathrm{C}$ bond scission using a barrier height of $12.3 \mathrm{kcal} \mathrm{mol}^{-1}$ in comparison to the $\mathrm{F}$ elimination process occurring with a barrier height of $28.0 \mathrm{kcal} \mathrm{mol}^{-1}$. The thermal rate constant evaluated using conventional transition state theory for the $\mathrm{C}-\mathrm{C}$ bond scission decomposition pathway is found to be $1.3 \times 10^{4} \mathrm{~s}^{-1}$ at $298 \mathrm{~K}$ and 1 atm pressure.

Acknowledgments. The authors are thankful to University Grants Commission. New Delhi for providing fellowships to BKM and NKG under its DSA (Phase-I) program to the Department of Chemistry. DDU Gorakhpur University, Gorakhpur

\section{References}

1. Molina, M. I.: Rowland, F. S. Kature 1974. 279,810.

2. Anderson, I. G.: Toohey, D. W. Brune, W. H. Science 1991, 39 , 251

3. Rowland. F. S. Ambio. 1990, 19, 281 .

4. Rowland, F. S.; Molina, M. J. Chem. Eng. News. 1994, 8, 72.
5. Hoffman, J. S. Ambio. 1990, 19, 329

6. Solomon, S. Natture $1990,347,6291$

7. Rowland, F. S. Ant Rev Phys. Chemt 1991, 42,731

8. Atkinson, R. In Scientific Assessment of Stratospheric Ozone, Vol II. World Meteorological Organization Global Ozone Research and Monitoring Project report No-20, 1989

9. World Meteorological Organization. Scientific Assessment of Ozone Depletion Report No 47, Global Ozone Research and Monitoring Project, 2002.

10. Gierczak, T.: Talukdar, R.: Vaghịani, G. L.: Lovejoy, E. R:; Ravishankara, A. R. J. Geophss. Rev. 1991, 96,5001

11. Atkinson, R. J. Phys. Chent 1989, 18, 1.

12. Brasseur, G. P.; Orlando, J. J. Atmospheric Chentisty and Global Change; Oxford University Press: New York, 1999.

13. Wallington, T. I; Hurley, M. D. Francheboud, J. M.; Orlando, J. J.: Tyndall, G. S.; Sehested, I. Mogelberg,T. E.: Nielsen, O. J. J. Phys Chem 1996, 100, 18116.

14. Wallington, T. T.; Hurley, M. D; Anderson, M. P; Tott, A. $J$. Phys. Chen t 2005, 109,9061.

15. Hehre, W. I.: Radom, L.; Schleyer, P. V. R.; Pople, I. A. Ab hitio Molecular Orbital Theon: Wiley: New York 1986.

16. Frisch, M. J. et al. Gaussian 03 (Revision C.02); Gallssian Inc:; Walling ford, CT, 2004.

17. Becke, A. D. J. Chent. Phys. 1993, 98, 5648

18. Lee, C; Yang, W: Parr, R. G. Phys. Rev. 1988, 37, 785

19. Gonzalez, C.; Schlegel, H. B. J. Chem. Phus 1989, 90, 2154.

20. Gonzalez, C.; Schlege, H. B. J. Chem. Phus 1990, 94, 5523.

21. Pople, J. A; Head-Gordan, M: Raghavachari, K. J. Chem, Phws. $1987,87,5968$.

22. Watts, J. D.; Gauss, T.; Bartlett, R. T. Chent. Phys. Letr. 1992, $200,1$.

23. Frisch, A.: Nielsen, A. B:; Holder, A. J. Ganssliew Lisers Mamal: Gaussian Inc: 2000.

24. Hou, H.: Wang. B. Phys. Chem. Chem. Phys. 2000, 2, 61.

25. Truhlar, D. G.; Garrett, B. C.; Klippenstein, S. J. J. Phys. Chem. $1996,100,12771$.

26. Wigner, E. P. Z Phs. Chem 1932, B19, 203.

27. Stevens, J. E.; Khayat, R. A. J.: Radkevich, O.; Broun, I. J. Phys Chem. 2004, 108, 11354.

28. Caralp, F; Devolder, P; Fittschen, C.; Gomez, N.; Hippler, H.; Mereau, R.; Rayez, M. T.; Striebel, F.; Viskolcz, B. Phys. Chen. Chem. Phys. 1999, 1, 2935. 